\title{
Catalytic ozonation for removal of antibiotic oxy-tetracycline using zinc oxide nanoparticles
}

\author{
Maha K. Mohsin ${ }^{1} \cdot$ Ahmed A. Mohammed ${ }^{1}$
}

Received: 19 October 2020 / Accepted: 26 November 2020 / Published online: 3 January 2021

(c) The Author(s) 2021

\begin{abstract}
The traditional wastewater treatment plants are mostly not designed to deal with polar micropollutants such as pharmaceuticals. Therefore, antibiotics must be completely removed before their emission to ecosystems. Catalytic ozonation is used to increase the efficiency of sole ozonation further. In the present study, semi-batch experiments were conducted to investigate the efficiency of sole ozonation and catalytic ozonation in the degradation of oxy-tetracycline (OTC) as an environmental hazards contaminant in an aqueous solutions. Zinc oxide nanoparticles $(\mathrm{ZnO})$ were used as a catalytic agent with ozone $\left(\mathrm{ZnO} / \mathrm{O}_{3}\right)$. The influence of operational parameters such as $\mathrm{pH}(3-11)$, initial oxy-tetracycline concentration (10-100) $\mathrm{mg} / \mathrm{l}$, temperature $(15-35)^{\circ} \mathrm{C}$, ozone generation rate $(0.138-1.38) \mathrm{mg} / \mathrm{s}$ and catalyst dosage $(25-200) \mathrm{mg} / \mathrm{l}$ on the $\mathrm{ZnO} / \mathrm{O}_{3}$ process was investigated. Ozone dosage was found to have the noticeable effect on the degradation process; however, the $\mathrm{ZnO}$ dosage was found to be less effective. The optimum condition was $1.38 \mathrm{mg} / \mathrm{s}$ at $\mathrm{pH}=7$, and after $35 \mathrm{~min}$, a $94 \%$ of OTC removal was achieved. The results demonstrated that catalytic ozonation was a very effective method for degradation and mineralization of OTC in aqueous solution.
\end{abstract}

Keywords Oxy-tetracycline $\cdot$ Catalytic ozonation $\cdot \mathrm{ZnO}$ nanoparticles $\cdot$ Removal efficiency

$\begin{array}{ll}\text { Abbreviations } \\ \text { OTC } & \text { Oxy-tetracycline } \\ \text { AOPs } & \text { Advanced oxidation processes } \\ \text { SOP } & \text { Sole ozonation processes } \\ \text { COP } & \text { Catalytic ozonation processes } \\ \mathrm{O}_{3} & \text { Ozone }\end{array}$

\section{Introduction}

Various pollutants are emerging in our environment,these pollutants that can cause an environmental problem inside water system (Alwared and Jaber 2020). In the recent years, environmental pollution with pharmaceutical antibiotics has attracted more attention due to their effect on the environmental and human health (Mohammed et al. 2020). Antibiotics are a large group of medicines used to treat

Maha K. Mohsin

maha.kh.mo.1991@gmail.com

Ahmed A. Mohammed

ahmed.abedm@yahoo.com

1 Environmental Engineering Department, College of Engineering, University of Baghdad, Baghdad, Iraq infectious diseases in humans and animals caused by various types of bacteria. According to reports, about $15 \%$ of the world's total manufactured drugs are antibiotics (Nasseh et al. 2019). Pharmaceutical antibiotics are biologically active compounds that are often soluble in water, but not easily biodegradable in natural circumstances. About 70\% of consumed antibiotics cannot be metabolized, including hospital effluents, treatment plant wastewater, and livestock excretion from feces and urine (Mohammed et al. 2020). The low antibiotic concentration in the aqueous environment (1-100 ppb), its presence in human drink water may cause diarrhea, headaches, nausea, tremors, vomiting, etc. (Mohammed et al. 2019b). Because of their reduced elimination by conventional wastewater treatment processes, various antibiotics have been released into the aqueous site by a sewage treatment plants (STP). Actually, many antibiotics, for example, sulfonamides, and oxy-tetracycline have been discovered downstream of STP release sites, in sea and river in various countries (Tran et al. 2018). Antibiotic resistance bacteria has been appear as a result of the existence of little concentration of antibiotic and their alteration products in the aquatic environment that create the right condition and movement and efficiency of removal of these concentrations in treatment plants has been incomplete (Boxall et al. 2003; 
Li et al. 2008). Oxy-tetracycline (OTC) is the most wildly used in agricultural activities for antibiotic application to enhance survival rate of embryo; meanwhile, it normally decays very slowly in nature due to its complex chemical structure. As a result, there are many research teams have tried to develop efficient technique to remove OTC (Kimera et al. 2015; Kerdnawee et al. 2017). Advanced oxidation processes (AOPs) have been excessive possible to eliminate various pollutants. AOPs have the advantage of rapid oxidation of pollutants to harmless end products (Alwared et al. 2014). AOPs such as Fenton, photocatalytic oxidation and ozonation were used to remove antibiotics (Trovó et al. 2009; Hou et al. 2013a; Hou et al. 2013b; Salman et al. 2020). Catalytic Ozonation, one of the most important processes of AOPs, currently used for removing organic compounds in a minimum process time and enormous removal rate (Amutha et al. 2014; Bai et al. 2016). AOPs include in situ generation of very reactive oxygen species (ROS) by small selectivity, for example, superoxide anion radicals $\left(\mathrm{O}_{2}^{-}\right), \mathrm{H}_{2} \mathrm{O}_{2}, \mathrm{O}_{3}$ and hydroxyl radicals $(\mathrm{HO})$, with wide-ranging degradation to $\mathrm{CO}_{2}, \mathrm{H}_{2} \mathrm{O}$ and inorganic ions or acids (Dalrymple et al. 2007; Kanakaraju et al. 2018). Combining ozonation with catalysis have been used to enhance the removal of antibiotics and their products (Nawrock and Kasprzyk-Hordern 2010; Kråkström et al. 2020). Catalysts used in combination with ozonation can be either homogenous or heterogeneous. The advantage of heterogeneous catalyst is the easy separation of the catalyst from the liquid and the possibility to reuse the catalyst (Gharbani and Mehrizad 2014). Among the catalysts, metal oxides, such as zinc oxide $(\mathrm{ZnO})$ nanoparticles, have a high potential for application in water and wastewater treatment due to their high surface area and low cost of production (Nasseh et al. 2019). In addition, $\mathrm{ZnO}$ has a number of antimicrobial, adsorptive, and toxicant favorable degradation properties (Cuerda-Correa et al. 2019).

The aim of this work is to investigate the removal rate of OTC via sole (SOP) and catalytic ozonation process(COP) by using $\mathrm{ZnO}$ nanoparticle, through various operating variables, including catalyst dose, temperature, ozone generation rate, and initial OTC concentration.

\section{Mechanism of ozonation}

Ozonation might be a promising process for antibiotics degradation that is providing advantages such as its ability to degrade organic and inorganic pollutants, with no chemical sludge remaining after the process, and have less danger for the reason that no stock of any chemical (like hydrogen peroxide) is critical and remaining ozone can be decomposed easily to oxygen in water (Gharbani and Mehrizad 2014). Two ways that takes place in the mechanism of oxidation by ozone: Direct reaction with liquefied ozone $\left(\mathrm{O}_{3}\right)$, its great oxidation potential $\left(\mathrm{E}^{\circ}=2.08 \mathrm{~V}\right)$ or indirect oxidation through the formation of radicals $(\mathrm{OH})$. The extension of both mechanisms throughout the degradation of a compound depends on factors such as the nature of the contaminant, the dose of ozone, or the $\mathrm{pH}$ of the medium. Normally, under acidic conditions $(\mathrm{pH}<4)$, direct ozonation prevails

$\mathrm{OH}^{-}+\mathrm{H}^{+}+3 \mathrm{O}_{3} \rightarrow 4 \mathrm{O}_{2}+2 \mathrm{OH}$

However, on the other hand, the indirect way at $\mathrm{pH}>9$ is the utmost important one. Normally, degradation rates in ozonation processes rise as $\mathrm{pH}$ does, free radicals as in reaction (2) from the decomposition of ozone in the base medium. Oxidative indirectly reaction with ozone is like these:

$\mathrm{OH}^{-}+\mathrm{O}_{3} \rightarrow \mathrm{O}_{2}+\mathrm{HO}_{2}^{-}$

$\mathrm{HO}_{2}^{-}+\mathrm{O}_{3} \rightarrow \mathrm{O}_{3}^{-}+\mathrm{HO}_{2}$

$\mathrm{HO}_{2}+\mathrm{O}_{2}^{-}+\mathrm{H}^{+}$

$\mathrm{O}_{2}^{-}+\mathrm{O}_{3} \rightarrow \mathrm{O}_{3}^{-}+\mathrm{O}_{2}$

$\mathrm{H}^{+}+\mathrm{O}_{3}^{-} \rightarrow \mathrm{HO}_{3}$

$\mathrm{HO}_{3} \rightarrow \mathrm{HO}+\mathrm{O}_{2}$

At base surroundings, the reaction can be taken into account:

$\mathrm{HO}+\mathrm{O}_{3} \rightarrow \mathrm{HO}^{2}+\mathrm{O}_{2}$

A reduction in the oxidation capacity in this reaction results in a fast hydroperoxyl radicals generation $\left(\mathrm{E}^{\circ}=1.65 \mathrm{~V}\right)$ as a result, the $\mathrm{OH}$ radicals $\left(\mathrm{E}^{\circ}=2.80 \mathrm{~V}\right)$; detriment and that led to eliminate oxidation capacity (CuerdaCorrea et al. 2019).

\section{Catalytic ozonation}

catalytic ozonation process can be used to enhance the degradation efficiency of organic pollutants, including homogeneous and heterogeneous catalytic ozonation. In homogeneous catalytic ozonation process, liquid catalysts, especially transition metal ions are used, such as $\mathrm{Co}^{+2}, \mathrm{Cd}^{+2}, \mathrm{Ag}^{+1}, \mathrm{Cr}^{+3}$, $\mathrm{Zn}^{+2}, \mathrm{Fe}^{+2}, \mathrm{Mn}^{+2}$ in reaction solution. These catalysts can excite ozone to generate hydroxyl radicals $(\mathrm{OH})$ and improve degradation efficiency. In heterogeneous catalytic ozonation process, solid catalysts such as metal oxide, activated carbon, porous materials, and their composite materials are 
added into reaction solution (Kasprzyk-Hordern et al. 2003; Wang and Zhuan 2019).

\section{Materials and methods}

\section{Chemicals}

Powder oxy-tetracycline (OTC), Molecular formula $\left(\mathrm{C}_{22} \mathrm{H}_{24} \mathrm{~N}_{2} \mathrm{O}_{9}\right)$, Molecular weight $(460.4 \mathrm{~g} / \mathrm{mol})$, water solubility $>100 \mathrm{mg} / \mathrm{ml}\left(21^{\circ} \mathrm{C}\right)$, was achieved from general company for drugs industry (Samarra, Iraq), zinc oxide ( $\mathrm{ZnO}$ ) with particle size $(30 \mathrm{~nm})$. The $\mathrm{pH}$ value of solutions has been controller through the experiments by addition of $0.1 \mathrm{M} \mathrm{NaOH}$ or HCL. Stock solution of OTC was arranged by dissolving a suitable amount of OTC powder antibiotic in $1 \mathrm{~L}$ of distilled water. Due to the unpredictability in the laboratory environments, the preparation of stock solutions at the experimental work time. The structure and properties of OTC are shown in Fig. 1. (Li et al. 2008).

Figure 2 shows the schematic diagram of the semi-batch reactor for ozonation experiments. The setup contains $1 \mathrm{~L}$ glass stirrer reactor, an oxygen source with high-purity (>98\% by volume), an ozone generator (Shanghai ENALY M\&E; model: OZX05K), and a gas distribution system (i.e., diffuser) to generate micro bubbles. $1 \mathrm{~L} / \mathrm{min}$ of $\mathrm{O}_{2}$ flow rate of was supplied to the ozone generator which was used to convert oxygen gas to ozone gas by the corona-discharge technique. To mix the water continuously, magnetic stirrer was used. The samples were collected at specified period time, centrifuged at $2000 \mathrm{rpm}$ for $10 \mathrm{~min}$ to separate catalyst from taken sample and then measure OTC concentrations.

\section{Analytical method}

$\mathrm{pH}$ was measured by the use of a $\mathrm{pH}$ meter (ISOLAB.). The temperature controlled by magnetic stirrer. The initial and remaining OTC concentrations have been determine in accordance with the standardization records that were gotten via UV/VIS spectrophotometers (Model: Cary-100 conc., Varian, USA)., with a peak wavelengths at $274 \mathrm{~nm}$ according to the absorbance analysis.<smiles>CN(C)C1C(O)=C(C(N)=O)C(=O)C2C(O)=C3C(=O)c4c(O)cccc4[C@@](C)(O)C3C(O)C21</smiles>

Fig. 1 Structure of oxy-tetracycline (Li et al. 2008)

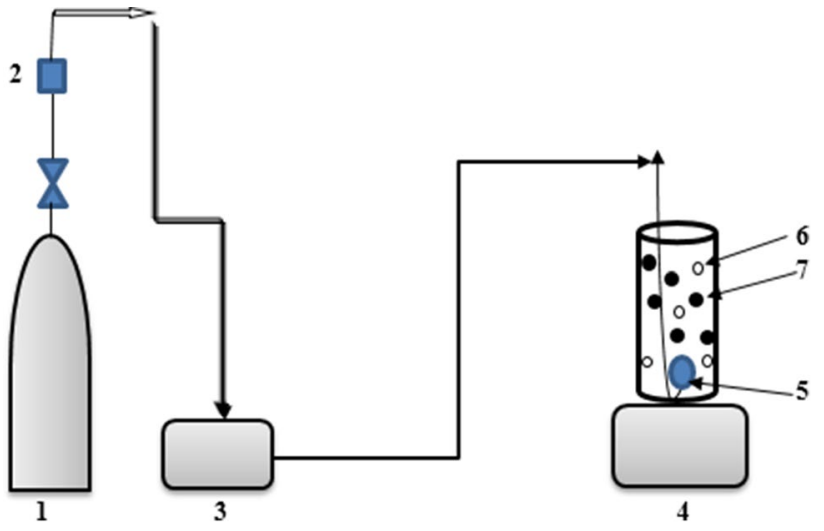

Fig. 2 Graphic diagram of the experimental set-up: (1) Oxygen source (2) Flow meter (3) Ozone generator (4) Magnetic stirrer (5) Diffuser (6) Ozone bubble (7) Catalyst particles

\section{Results and discussion}

\section{Characterization of $\mathrm{ZnO}$}

TEM image (Transmission Electron Microscopy) (Fig. 3) showed that the $\mathrm{ZnO}$ nanoparticles have an irregular shape, but most of them are roughly spherical with an average size of $<100 \mathrm{~nm}$. Thus, these particles are within the nano-size range. Also, the agglomeration of these nanoparticles is low, as their dispersion appears to be in a mono-dispersed manner (Mohammed et al. 2019a).

\section{Effect of pH}

The $\mathrm{pH}$ value is considered as one of the important factors affecting the behavior and fate of antibiotics in an environment. This parameter can effect on the route of degrading of organic pollutants by two ways. The first is the transportation of ozone from gas phase into liquid phase (direct effect).

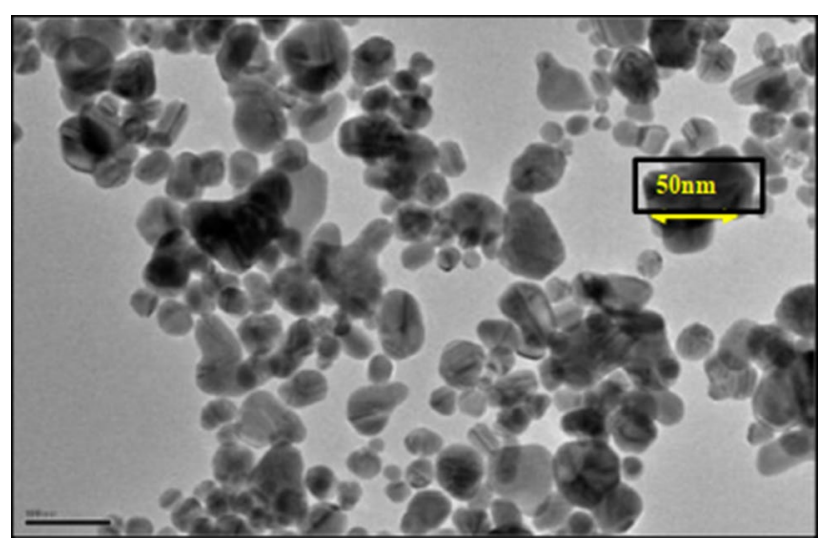

Fig. 3 TEM image of $\mathrm{ZnO}$ nanoparticles 
The second is degradation of ozone into various radicals (indirect effect) (Nasseh et al. 2019). In general, the rate of ozone decomposition increases with increasing solution $\mathrm{pH}$ since the hydroxyl ions catalyst the decay of ozone to form radicals serving as reactive species ( $\mathrm{Li}$ et al. 2008). In this study, the $\mathrm{pH}$ range was taken as $(3,5,7,9,11)$ to examine the effect of the media on the removal rate, the highest removal efficiency was observed at $\mathrm{pH}$ of $7(84 \%)$ at time $35 \mathrm{~min}$, similar to these results were also reported by $\mathrm{Li}$ et al. (2008) as shown in Fig. 4.

From Fig. 4, it can be seen that the degradation efficiency after 10 min increased not more than $6 \%$. At $\mathrm{pH}(3,5,7$, $9,11)$, the removal efficiency was $(80,82,84,83,81) \%$, respectively, after $35 \mathrm{~min}$ for OTC concentration of $50 \mathrm{mg} / \mathrm{l}$ and ozonation rate $=1.38 \mathrm{mg} / \mathrm{s}$. In the current study, $\mathrm{pH} 7$ has been found the best possible condition for the treatment of OTC. For OTC, its removal efficiency was showed slight dependence on $\mathrm{pH}$. Similar results were as well reported in the literature, for instance, the Ozonation of Methylene orange dye (Nashmi et al. 2019) and the Ozonation of $\mathrm{CN}^{-}$ions was studied by Rice (1997) it was pointed out that $\mathrm{pH}$ had slight effect on cyanide Ozonation to cyanate. In accordance with the mechanism predicted by Staehelin and Hogine (1985), $\mathrm{OH}^{-}$ions act in response with dissolved ozone to generate $\mathrm{O}_{2}^{-}$free radicals, and $\mathrm{H}^{+}$ions promote $\mathrm{O}_{2}^{-}$free radicals to convert into $\mathrm{HO}_{3}$ free radicals, which are in turn decomposed to $\mathrm{OH}$ free radicals (Sotelo et al. 1989). Both $\mathrm{H}^{+}$and $\mathrm{OH}^{-} \mathrm{H}^{+}$ions are needed for the production of $\mathrm{OH}$ free radicals. Additionally, the existence of acid/ base-active phenolic hydroxyl and amine groups in OTC (an amphoteric antibiotic) determines that OTC may exist in different ionic species at different solution pHs. The OTC molecule has three acid dissociation constants depending on the $\mathrm{pH}(\mathrm{pKa}=3.57,7.5$, and 9.44) and existed as cationic

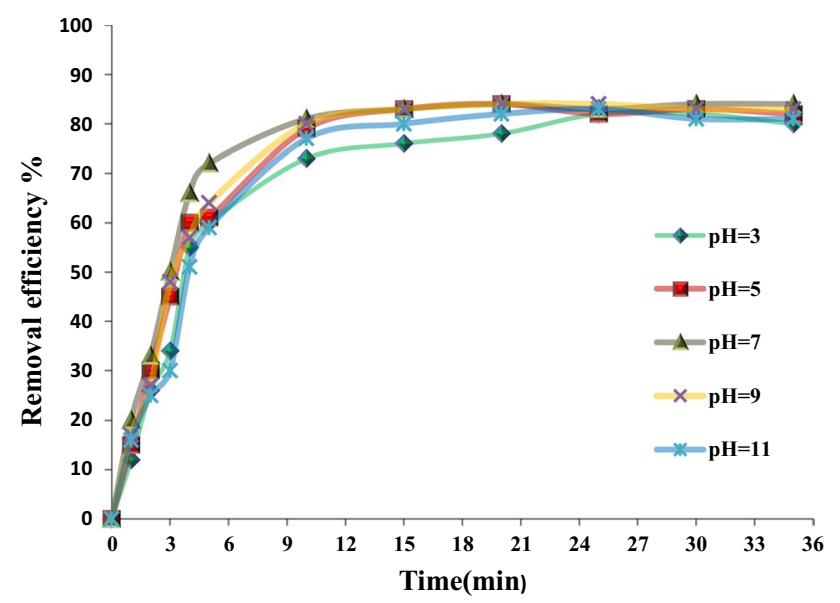

Fig. 4 The effect of $\mathrm{pH}$ with time on the removal efficiency of OTC (OTC conc. $=50 \mathrm{mg} / \mathrm{l}$, ozone generation rate $=1.38 \mathrm{mg} / \mathrm{s}$, reaction time $=35 \mathrm{~min}$, at room temp.) form in strong acid solutions at $\mathrm{pH}<3.57$, zwitterion at $3.57<\mathrm{pH}<7.5$ and anionic form at $\mathrm{pH}>7.5$ (Harja and Ciobanu 2017). Li et al. (2008) reported the by-products can be more oxidized to smaller molecules such as carbon dioxide and water.

Figure 5 shows the alteration of $\mathrm{pH}$ value during ozonation process. As it can be seen, the initial $\mathrm{pH}$ of 7, 9, and 11 decreases gradually most probably as a result of carboxylic acid accumulation in the process water. Under acidic conditions, the ozonation does not measurably affect the solution $\mathrm{pH}$. Similar to these results were also reported by Li et al. (2008).

\section{Effect of catalyst dosage}

Catalysts can provide active sites for catalytic or adsorptive reactions among ozone, liquid, and organic compounds; therefore, the usage of catalysts in aqueous solution is an essential factor. Generally, surface areas and the reactive sites can be increased by increasing the catalyst dose, (Huang et al. 2015). Meanwhile, a higher apparent reaction rate constant for catalytic ozonation would be obtained. However, considering the constant concentration of pollutants, excessive amount of catalyst would decrease the concentration of pollutants and ozone per unit area, which could decrease the catalytic efficiency (Nie et al. 2012). Therefore, it was necessary to optimize the catalyst dosage based on the experimental results. The efficiency of the catalytic ozonation process depends to a great extent on the catalyst and its surface properties as well as the $\mathrm{pH}$ of the solution that influences the properties of the surface active sites and ozone decomposition reactions in aqueous solutions (KasprzykHordern et al. 2003).

The catalytic ozonation performance of the $\mathrm{ZnO}$ was evaluated within $50 \mathrm{mg} / \mathrm{l}$ OTC initial concentration (Fig. 6). In the sole ozonation process, the degradation efficiency of OTC could only reach $81 \%$ within $10 \mathrm{~min}$. The addition of $\mathrm{ZnO}$ caused as important development

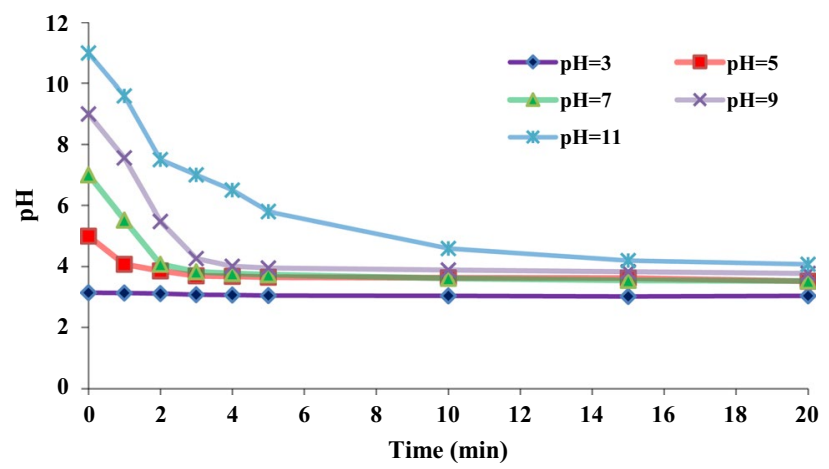

Fig. 5 Change of $\mathrm{pH}$ with time of OTC (OTC conc. $=50 \mathrm{mg} / \mathrm{l}$, ozone generation rate $=1.38 \mathrm{mg} / \mathrm{s}$, at room temp.) 


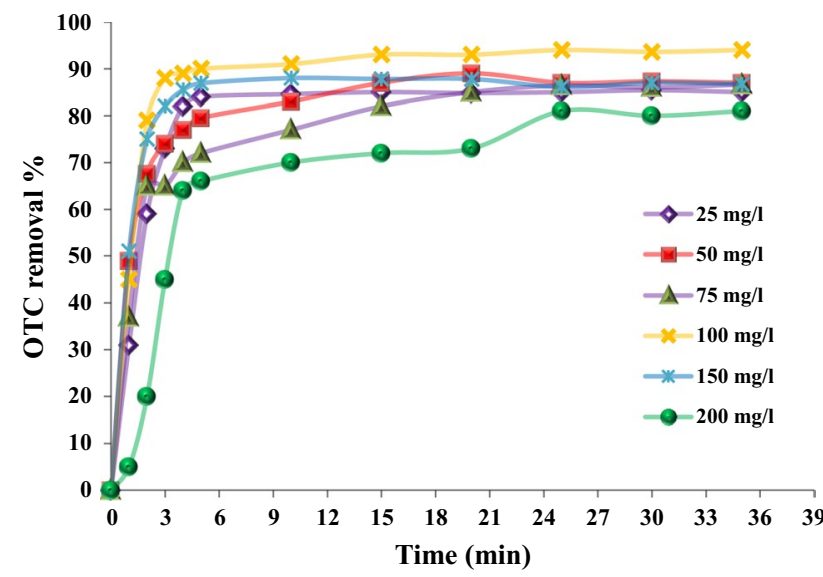

Fig. 6 The effect of $\mathrm{ZnO}$ dosage with time on the removal efficiency of OTC $($ OTC conc $=50 \mathrm{mg} / \mathrm{l}, \mathrm{pH}=7$, ozone generation rate $=1.38 \mathrm{mg} / \mathrm{s}$, at room temp.)

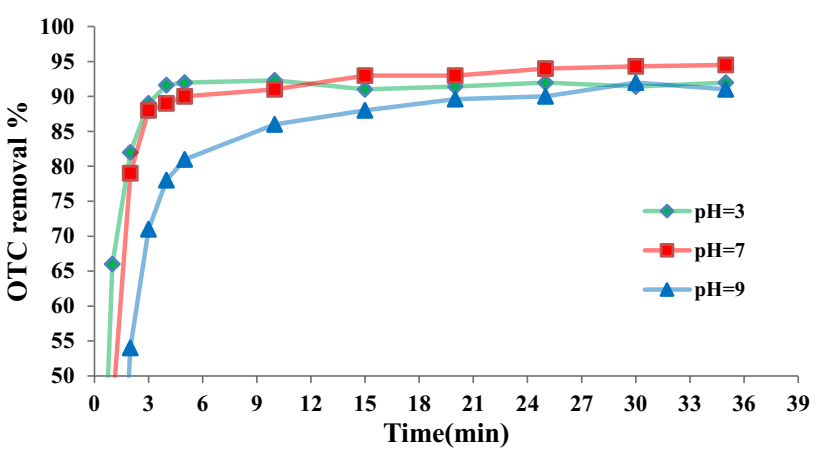

Fig. 7 The effect of $\mathrm{pH}$ on $\mathrm{ZnO}$ with time on the removal efficiency of OTC (OTC conc. $=50 \mathrm{mg} / \mathrm{l}, \mathrm{ZnO}=100 \mathrm{mg} / \mathrm{l}$, ozone generation rate $=1.38 \mathrm{mg} / \mathrm{s}$, at room temp.)

for the degradation of OTC. The efficiency of removal of OTC in the COP reached $91 \%$ within $10 \mathrm{~min}$ and reached $94 \%$ in $35 \mathrm{~min}$ at $100 \mathrm{mg} / \mathrm{lnO}$. The adsorptive removal would be neglected as the OTC adsorption onto nano$\mathrm{ZnO}$ was just about $6.5 \%$ after $60 \mathrm{~min}$. The experiment of absorption curried by add $200 \mathrm{ml}$ of the OTC solution (conc. $=50 \mathrm{mg} / \mathrm{L}$ ) in the flask at $\mathrm{pH}(3,5,7,9,11), \mathrm{ZnO}$ dosage $(100 \mathrm{mg} / \mathrm{L})$ and shaking for $60 \mathrm{~min}$ (figure not shown). It is signifying that the degradation of OTC was mainly caused by oxidation.

The dose of $\mathrm{ZnO}$ ( $100 \mathrm{mg} / \mathrm{l})$ was testing in different $\mathrm{pH}$ $(3,7$, and 9$)$, and finding the $\mathrm{pH} 7$ is the best to degradation of OTC as shown in Fig. 7

Figure 8 shows a combination between the degradation of OTC using different processes (oxidation by Oxygen, ozonation, catalytic ozonation, and adsorption OTC on $\mathrm{ZnO}$ ).

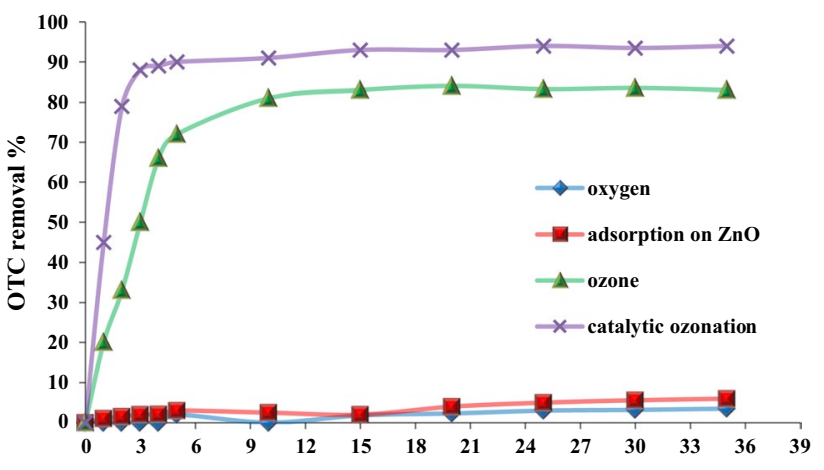

Fig. 8 Combination of removal efficiency for different processes for OTC (OTC concentration $=50 \mathrm{mg} / \mathrm{l}$, ozone generation rate $=1.38 \mathrm{mg} / \mathrm{s}$, at room temp.)

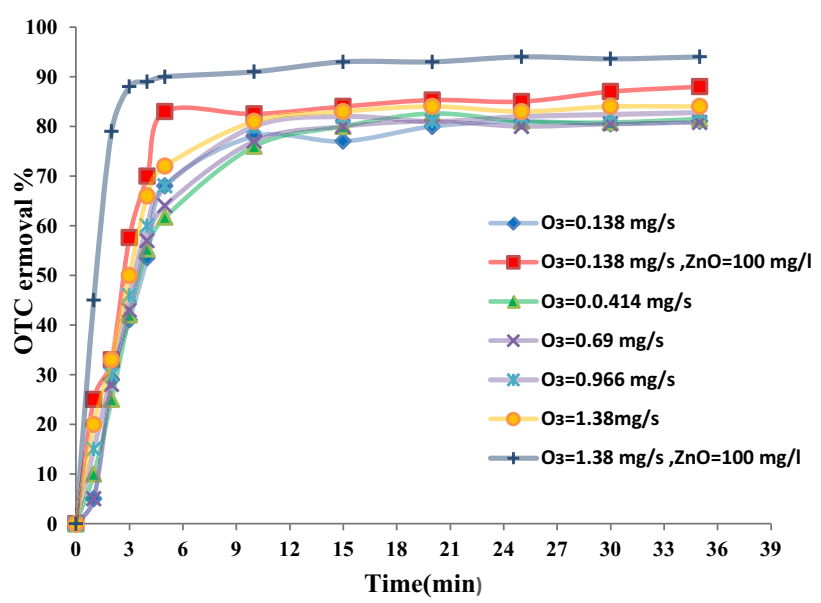

Fig. 9 Effect Of Ozonation Rate On OTC Removal Efficiency $(\mathrm{pH}=7$, OTC conc. $=50 \mathrm{mg} / \mathrm{l}$, at room temp)

\section{Effect of ozone generation rate}

Ozone generation rate will be changed from $0.138 \mathrm{mg} / \mathrm{s}$ to $1.38 \mathrm{mg} / \mathrm{s}$ at $\mathrm{pH}=7$ and constant OTC concentration $(50 \mathrm{mg} / \mathrm{L})$ to investigate its effect on the degradation rate of OTC. Figure 9 shows that degradation efficiency was enhanced with increasing the initial ozone concentration. Because an increase in the influent ozone gas concentration results in an increase in aqueous ozone concentration which either directly reacts with the OTC or decomposes to produce $H O$ which in turn reacts with the pollutant $(\mathrm{Li}$ et al. 2009). From Fig. 9, it was obviously shown when the generation rate of ozone increased from $0.138 \mathrm{mg} / \mathrm{sec}$ to $1.38 \mathrm{mg} / \mathrm{sec}$, the removal efficiency for OTC increases from 81 to $83 \%$ through $35 \mathrm{~min}$, while the degradation efficiency increased from 88 to $94 \%$ with increasing ozone generation rate from $0.138 \mathrm{mg} / \mathrm{s}$ to $1.38 \mathrm{mg} / \mathrm{s}$ in the presence of $100 \mathrm{mg} / \mathrm{ZnO}$ nanoparticle. This indicates that 
even with a little ozone concentration, the removal rate is high, this is an economical feature for treating antibiotics via ozonation process. The mass transfer rate and the volumetric mass transfer coefficient of ozone increases with increase in ozone concentration. More ozone can be absorbed and react with OTC molecules, finally improving the decomposition of OTC (Wang and Zhuan 2019). From Fig. 9, it can be seen that in SOP at $0.138 \mathrm{mg} / \mathrm{s}$, the removal efficiency reached $78 \%$ after $10 \mathrm{~min}$ and $81 \%$ after $35 \mathrm{~min}$, and at in COP, the removal efficiency reached $82.5 \%$ after $10 \mathrm{~min}$ and $88 \%$ after $35 \mathrm{~min}$. While, at $1.38 \mathrm{mg} / \mathrm{s}$ in SOP, the removal efficiency reached $81 \%$ after $10 \mathrm{~min}$ and $84 \%$ after $35 \mathrm{~min}$, and at in COP, the removal efficiency reached $91 \%$ after $10 \mathrm{~min}$ and $94 \%$ after $35 \mathrm{~min}$ for $\mathrm{pH}=7$, and OTC concentration of $50 \mathrm{mg} / \mathrm{l}$, $\mathrm{ZnO}=100 \mathrm{mg} / \mathrm{l}$. It is noted that the increased in removal efficiency from 10 to 35 min not more than $5 \%$.

\section{Effect of temperature}

Reaction temperature is an important parameter for almost all chemical reactions. Ozonation and catalytic ozonation are no exclusion as well. On the other hand, there are two different effects of increasing reaction temperature in SOP and COP, the first that increases reaction temperature can cause a quicker reaction rate between oxidizing agent and pollutants (Lan et al. 2013; Yan et al. 2013). On the other hand, the solubility of ozone in water is opposite to the temperature (Huang et al. 2011). In this work, temperature was taken as $(15,25,35)^{\circ} \mathrm{C}$ to investigate effect it's on the removal rate of OTC, the highest removal efficiency was observed at $15^{\circ} \mathrm{C}$ as shown in Fig. 10 . The above abnormal phenomena are caused by the balance of both the solubility of ozone and reaction rate of ozonation. On the other side, the solubility of ozone decreases in aqueous phase as the temperature rises (Giri et al. 2008), this led to decrease in

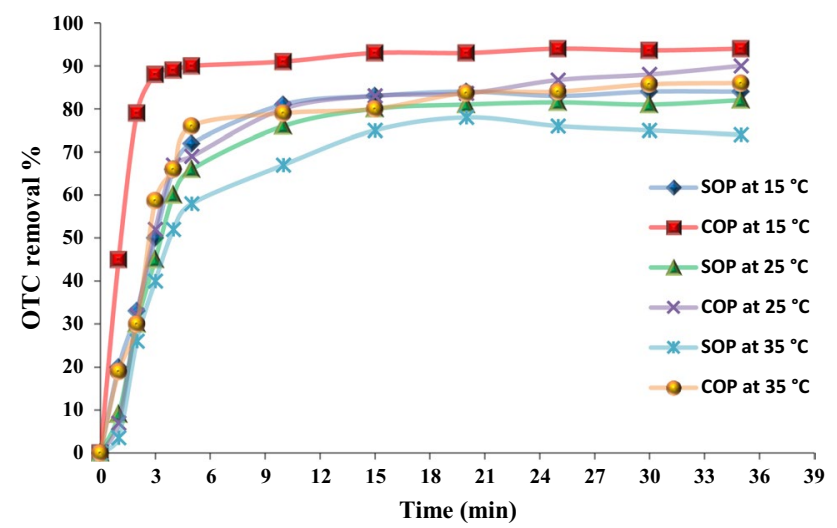

Fig. 10 The effect of temperature with time on the degradation efficiency of OTC (OTC conc. $=50 \mathrm{mg} / \mathrm{l}, \mathrm{pH}=7$, ozone generation rate $=1.38 \mathrm{mg} / \mathrm{s}, \mathrm{ZnO}=100 \mathrm{mg} / \mathrm{l})$
$\mathrm{HO}$ in the solution that oxidized OTC molecules. The same phenomenon is observed in a previous examination on using natural brucite to improve the ozonation of phenol (He et al. 2008), removal of tetracycline and ofloxacin by using nano$\mathrm{Mg}\left(\mathrm{OH}_{2}\right)$ (Lü et al. 2015). From Fig. 10, it can be seen that in SOP at $15{ }^{\circ} \mathrm{C}$, the removal efficiency reached $81 \%$ after $10 \mathrm{~min}$ and $84 \%$ after $35 \mathrm{~min}$, and at $35^{\circ} \mathrm{C}$, the removal efficiency reached $67 \%$ after $10 \mathrm{~min}$ and $74 \%$ after $35 \mathrm{~min}$ for $\mathrm{pH}=7$, ozonation rate $=1.38 \mathrm{mg} / \mathrm{s}$, and OTC concentration of $50 \mathrm{mg} / \mathrm{l}$. While, in COP at $15{ }^{\circ} \mathrm{C}$, the removal efficiency reached $91 \%$ after $10 \mathrm{~min}$ and $94 \%$ after $35 \mathrm{~min}$, and at $35{ }^{\circ} \mathrm{C}$, the removal efficiency reached $79 \%$ after $10 \mathrm{~min}$ and $86 \%$ after $35 \mathrm{~min}$ for $\mathrm{pH}=7, \mathrm{ZnO}=100 \mathrm{mg} / \mathrm{l}$, ozonation rate $=1.38 \mathrm{mg} / \mathrm{s}$, and OTC concentration of $50 \mathrm{mg} / \mathrm{l}$.

Reaction temperature is an important parameter for almost all chemical reactions. Ozonation and catalytic ozonation are no exclusion as well. On the other hand, there are two different effects of increasing reaction temperature in SOP and COP, the first that increases reaction temperature can cause a quicker reaction rate between oxidizing agent and pollutants (Lan et al. 2013; Yan et al. 2013). On the other hand, the solubility of ozone in water is opposite to the temperature (Huang et al. 2011). In this work, temperature was taken as $(15,25,35)^{\circ} \mathrm{C}$ to investigate effect it's on the removal rate of OTC, the highest removal efficiency was observed at $15{ }^{\circ} \mathrm{C}$ as shown in Fig. 10. The above abnormal phenomena are caused by the balance of both the solubility of ozone and reaction rate of ozonation. On the other side, the solubility of ozone decreases in aqueous phase as the temperature rises (Giri et al. 2008), this led to decrease in $\mathrm{HO}$ in the solution that oxidized OTC molecules. The same phenomenon is observed in a previous examination on using natural brucite to improve the ozonation of phenol (He et al. 2008), removal of tetracycline and ofloxacin by using nano$\mathrm{Mg}\left(\mathrm{OH}_{2}\right)$ (Lü et al. 2015). From Fig. 10, it can be seen that in SOP at $15{ }^{\circ} \mathrm{C}$, the removal efficiency reached $81 \%$ after $10 \mathrm{~min}$ and $84 \%$ after $35 \mathrm{~min}$, and at $35{ }^{\circ} \mathrm{C}$, the removal efficiency reached $67 \%$ after $10 \mathrm{~min}$ and $74 \%$ after $35 \mathrm{~min}$ for $\mathrm{pH}=7$, ozonation rate $=1.38 \mathrm{mg} / \mathrm{s}$, and OTC concentration of $50 \mathrm{mg} / \mathrm{l}$. While, in COP at $15{ }^{\circ} \mathrm{C}$, the removal efficiency reached $91 \%$ after $10 \mathrm{~min}$ and $94 \%$ after $35 \mathrm{~min}$, and at $35{ }^{\circ} \mathrm{C}$, the removal efficiency reached $79 \%$ after $10 \mathrm{~min}$ and $86 \%$ after $35 \mathrm{~min}$ for $\mathrm{pH}=7, \mathrm{ZnO}=100 \mathrm{mg} / \mathrm{l}$, ozonation rate $=1.38 \mathrm{mg} / \mathrm{s}$, and OTC concentration of $50 \mathrm{mg} / \mathrm{l}$.

\section{Influence of initial OTC concentration}

In the water environment (typically in nano-or micrograms per liter), antibiotics concentrations was commonly hard to carry out experiments with low concentrations in the laboratory and justly concentrations of high amounts of antibiotics are used for the purpose of experiments. Different concentrations were taken $(10,25,50,75,100) \mathrm{mg} / \mathrm{L}$, at $\mathrm{pH}=7$ 


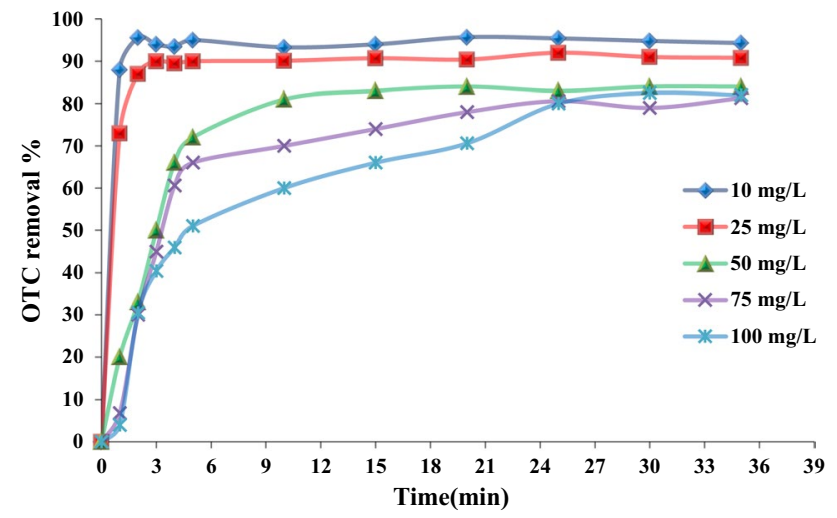

Fig. 11 Effect of the initial concentration OTC on the removal efficiency $(\mathrm{pH}=7$, ozone generation rate $=1.38 \mathrm{mg} / \mathrm{s}$, at room temp)

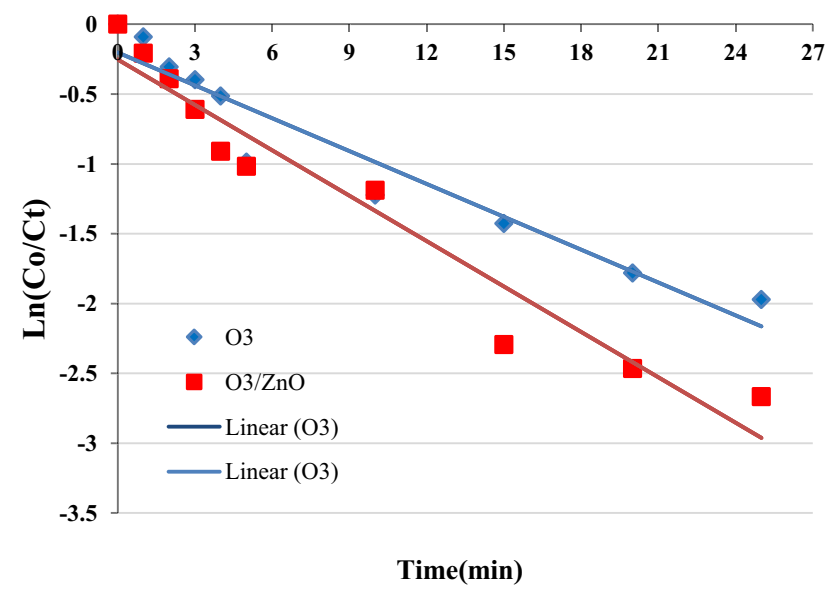

Fig. 12 Testing first-order kinetic for OTC

and the ozone generation rate is $1.38 \mathrm{mg} / \mathrm{s}$. Increasing in the OTC primary concentration results in reduction in the pollutant removal rate (Fig. 11). After 5 min and with the initial concentration of $10 \mathrm{mg} / \mathrm{L}$, the degradation efficiency of OTC gotten $95 \%$, Although for $50,100 \mathrm{mg} / \mathrm{L}$ were only $72 \%, 51 \%$, respectively, showing that more OTC is oxidized by ozone at lower initial concentration. This can be unstated by considering that the reaction follows first order kinetics (Fig. 12). Increasing OTC initial concentration causes increase in the concentration of degradation intermediates, as a result, extra ozone consumption for the more removal and oxidation of by-products (Lü et al. 2015; Li et al. 2009; Sun et al. 2019).

\section{Kinetics study}

In the present study, the kinetics of OTC degradation was studied for both SOP and COP, and the theoretical and experimental data are depicted in Figs. 12 and 13. The applicability and validation of the first- and second-order

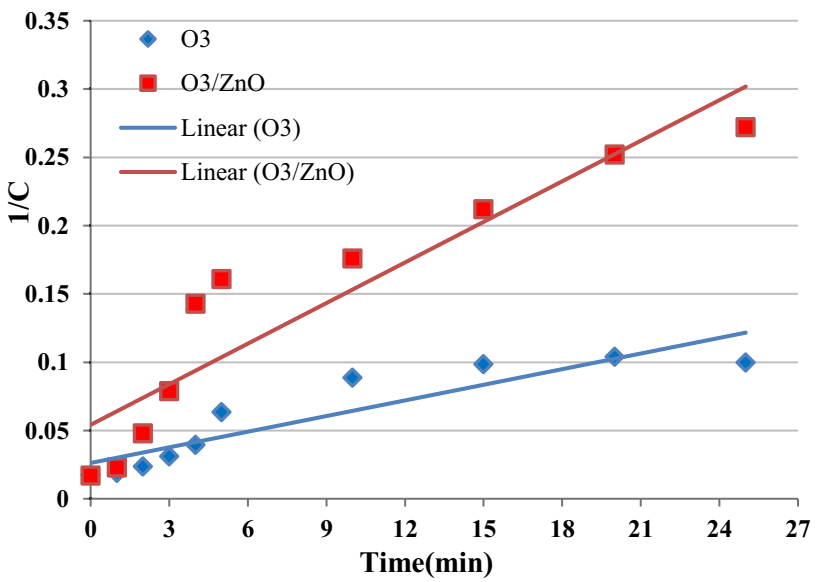

Fig. 13 Testing second-order kinetic for OTC

Table 1 The results of experimental kinetic data of degradation in SOP and COP reaction with the first-order equation

\begin{tabular}{llll}
\hline Type of process & $\begin{array}{l}\text { Equation, where } \mathrm{Y}=\mathrm{Ln}( \\
\mathrm{C} / \mathrm{Co}), \text { and } \mathrm{x}=\mathrm{t}\end{array}$ & $\mathrm{k}_{\mathrm{a}}(1 / \mathrm{min})$ & $\mathrm{R}^{2}$ \\
\hline $\mathrm{O}_{3}$ only & $\mathrm{Y}=-0.0784 \times-0.2034$ & 0.078 & 0.9269 \\
$\mathrm{O}_{3} / \mathrm{ZnO}$ & $\mathrm{Y}=-0.1083 \times-0.2541$ & 0.108 & 0.9436 \\
\hline
\end{tabular}

Table 2 The results of experimental kinetic data of degradation in $\mathrm{SOP}$ and COP reaction with the second-order equation

\begin{tabular}{llll}
\hline Type of process & $\begin{array}{l}\text { Equation, where } \mathrm{Y}=\mathrm{Ln}( \\
\mathrm{C} / \mathrm{Co}), \text { and } \mathrm{x}=\mathrm{t}\end{array}$ & $\mathrm{k}_{\mathrm{a}}(1 / \mathrm{min})$ & $\mathrm{R}^{2}$ \\
\hline $\mathrm{O}_{3}$ only & $\mathrm{Y}=0.0038 \times+0.0262$ & 0.0038 & 0.8343 \\
$\mathrm{O}_{3} / \mathrm{ZnO}$ & $\mathrm{Y}=0.0099 \times+0.0541$ & 0.0099 & 0.8592 \\
\hline
\end{tabular}

model and Eq. (9) were judged according to the values of determination of coefficient $\left(\mathrm{R}^{2}\right)$. However, the kinetic reaction rate parameter $\left(\mathrm{k}_{\mathrm{a}}\right)$ for first-order model is determined from the slope of the best fit line of the plot of $\mathrm{Ln}$ $(\mathrm{C} / \mathrm{Co})$ versus reaction time $(\mathrm{t})$, to second-order model is determined from the slope of the best fit line of the plot of (1/C) (Nasseh et al. 2019). The results of these parameters are listed in Table 1 and Table 2. It can be seen that the first-order model fitted well the kinetic data (Fig. 12) as high well $\mathrm{R}^{2}$ values were obtained ( $>0.9$ ). (In addition, in catalytic ozonation process the $\mathrm{k}_{\mathrm{a}}$ values significantly increased. Furthermore, the $\mathrm{k}_{\mathrm{a}}$ values determined were high, a high degradation of OTC (1).

$\operatorname{In}\left(\frac{C_{t}}{C_{o}}\right)=-k_{a} t$ 
where $\mathrm{k}_{\mathrm{a}}\left(\mathrm{min}^{-1}\right)$ is the rate constant for pseudo-firstorder reaction, and $\mathrm{t}(\mathrm{min})$ represents the specific reaction time.

\section{Conclusion}

The obtained results indicate that the catalytic ozonation by $\mathrm{ZnO}$ nanoparticles could be an efficient treatment to degrade oxy-tetracycline in comparison with sole ozonation process. The degradation efficiency of OTC in catalytic ozonation $\left(\mathrm{ZnO} / \mathrm{O}_{3}\right)$ process was found to have the noticeable effect on the efficiency of removal and decrees of reaction time by $93 \%$ and $15 \mathrm{~min}$, respectively. The effect of $\mathrm{pH}$ was investigated, and it was found that the OTC removal rate was showed slight dependence on $\mathrm{pH}$. The effect of temperature on the catalytic ozonation of OTC was investigated, and it was found that the OTC removal rate increased with decrease in temperature. Also, the effect of increasing initial concentration of OTC was investigated, and it was found that with the increase in the initial concentration of antibiotic in the aqueous solution, the degradation efficiency of these antibiotics by ozone molecules decreases.

Funding This research did not receive any specific grant from funding in the public, commercial, or not- for-profit sectors.

\section{Compliance with ethical standard}

Conflict of interest All authors have participated in (a) conception and design, or analysis and interpretation of the data; (b) drafting the article or revising it critically for important intellectual content; and (c) approval of the final version. This manuscript has not been submitted to, nor is under review at, another journal or other publishing venue. The authors have no affiliation with any organization with a direct or indirect financial interest in the subject matter discussed in the manuscript. On behalf of all authors, the corresponding author states that there is no conflict of interest.

Open Access This article is licensed under a Creative Commons Attribution 4.0 International License, which permits use, sharing, adaptation, distribution and reproduction in any medium or format, as long as you give appropriate credit to the original author(s) and the source, provide a link to the Creative Commons licence, and indicate if changes were made. The images or other third party material in this article are included in the article's Creative Commons licence, unless indicated otherwise in a credit line to the material. If material is not included in the article's Creative Commons licence and your intended use is not permitted by statutory regulation or exceeds the permitted use, you will need to obtain permission directly from the copyright holder. To view a copy of this licence, visit http://creativecommons.org/licenses/by/4.0/.

\section{References}

Alwared AI, Jaber WSh (2020) Spiral path three phase fluidized bed reactor for treating wastewater contaminated with engine oil. Applied Water Science 10:208

Alwared AI, Mustafa YA, Ebrahim M (2014) Heterogeneous Photocatalytic Degradation for Treatment of Oil from Wastewater. Khwarizmi Eng J 10(3):53-61

Amutha R, Sillanpää M, Lee GJ, Lin JC, Yang CK, Wu JJ (2014) Catalytic ozonation of 2-ethoxy ethyl acetate using mesoporous nickel oxalates. Catal Commun 43:88-92

Bai Z, Yang Q, Wang J (2016) Catalytic ozonation of sulfamethazine using $\mathrm{Ce} 0.1 \mathrm{Fe} 0.9 \mathrm{OOH}$ as catalyst: Mineralization and catalytic mechanisms. Chem Eng J 300:169-176

Boxall ABA, Kolpin DW, Halling-Sørensen B, Tolls J (2003) Are veterinary medicines causing environmental risks. Environ Sci Technol 37:286A-294A

Cuerda-Correa EM, Alexandre-Franco MF, Fernández-González C (2019) Advanced oxidation processes for the removal of antibiotics from water. An Overview. Water Res 12:102

Dalrymple OK, Yeh DH, Trotz MA (2007) Removing pharmaceuticals and endocrine-disrupting compounds from wastewater by photocatalysis. J Chem Technol Biotechnol 82:121-134

Gharbani P, Mehrizad A (2014) Heterogeneous catalytic ozonation process for removal of 4-chloro-2-nitrophenol from aqueous solutions. J Saudi Chem Soc 18(5):601-605

Giri RR, Ozaki H, Taniguchi S, Takanami R (2008) Photocatalytic ozonation of 2, 4-dichlorophenoxyacetic acid in water with a new TiO2 fiber. Int J Environ Sci Technol 5:17-26

He K, Dong YM, Li Z, Yin L, Zhang AM, Zheng YC (2008) Catalytic ozonation of phenol in water with natural brucite and magnesia. J Hazard Mater 159:587-592

Hou L, Zhang H, Wang L, Chen L, Xiong Y, Xue X (2013a) Removal of sulfamethoxazole from aqueous solution by sono-ozonation in the presence of a magnetic catalyst. Sep Purif Technol 117:46-52

Hou L, Zhang H, Wang L, Chen L (2013b) Ultrasoundenhanced magnetite catalytic ozonation of tetracycline in mwater. Chem Eng J 229:577-584

Huang R, Yan H, Li L, Deng D, Shu Y, Zhang Q (2011) Catalytic activity of Fe/SBA-15 for ozonation of dimethyl phthalate in aqueous solution. Appl Catal B 106:246-271

Huang Y, Cui C, Zhang D, Li L, Pan D (2015) Heterogeneous catalytic ozonation of dibutyl phthalate in aqueous solution in the presence of iron-loaded activated carbon. Chemosphere 119:295-301

Kanakaraju D, Beverley D, Oelgemoller M (2018) Advanced oxidation process-mediated removal of pharmaceuticals from water: A review. J Environ Manag 219:189-207

Kasprzyk-Hordern B, Ziolek M, Nawrocki J (2003) Catalytic ozonation and methods of enhancing molecular ozone reactions in water treatment. Appl Catal BEnviron 46:639-669

Kerdnawee K, Kuptajit P, Sano N, Tamon H, Chaiwat W, Charinpanitkul T (2017) Catalytic ozonation of oxy-tetracycline using magnetic carbon nanoparticles. J Jpn Inst Energy 96:362

Kimera ZI, Mdegela RH, Mhaiki CJ, Karimuribo ED, Mabiki F, Nonga HE, Mwesongo J, Onderstepoort J (2015) Vet Res 82:911

Kråkström M, Saeid S, Tolvanen P, Salmi T, Eklund P, Kronberg L (2020) Catalytic ozonation of the antibiotic sulfadiazine: reaction kinetics and transformation mechanisms. Chemosphere 247:125853

Lan B, Huang R, Li L, Yan H, Liao G, Wang X, Zhang Q (2013) Catalytic ozonation of $\mathrm{p}$-chlorobenzoic acid in aqueous solution using Fe-MCM-41 as catalyst. Chem Eng J 219:346-354 
Li K, Yediler A, Yang M, Schulte-Hostede S, Wong MH (2008) Ozonation of oxytetracycline and toxicological assessment of its oxidation by-products. Chemosphere 72:473-478

Li L, Ye W, Zhang Q, Sun F, Ping L, Li X (2009) Catalytic ozonation of dimethyl phthalate over cerium supported on activated carbon. J Hazard Mater 170:411-416

Lü X, Zhang Q, Yang W, Li X, Zeng L, Li L (2015) Catalytic ozonation of 2,4-dichlorophenoxyacetic acid over novel Fe-Ni/AC. RSC Advances 5:10537-10545

Harja M, Ciobanu G (2017) Removal of oxytetracycline from aqueous solutions by hydroxyapatite as a low-cost adsorbent. E3S Web Conf 22:00062

Mohammed AA, Al-Musawi TJ, Kareem SL, Zarrabi M, Al-Ma'abreh AM (2019a) Simultaneous adsorption of tetracycline, amoxicillin, and ciprofloxacin by pistachio shell powder coated with zinc oxide nanoparticles. Arab J Chem 13:4632

Mohammed AA, Atiya MA, Hussein MA (2019b) Studies on membrane stability and extraction of ciprofloxacin from aqueous solution using pickering emulsion liquid membrane stabilized by magnetic nano- $\mathrm{Fe}_{2} \mathrm{O}_{3}$. Colloids Surf A 585:124044

Mohammed AA, Atiya MA, Hussein MA (2020) Simultaneous studies of emulsion stability and extraction capacity for the removal of tetracycline from aqueous solution by liquid surfactant membrane. Chem Eng Res Design 159:225-235

Nashmi OA, Mohammed AA, Abdulrazzaq NN (2019) Investigation of ozone microbbubles for the degradation of methylene orange contaminated wastewater. Iraq J Chem Pet Eng 21(2):25-35

Nasseh N, Arghavan FS, Couto SR, Panahi AH, Esmati M, A-Musawi TJ (2019) Preparation of activated carbon@ZnO composite and its application as a novel catalyst in catalytic ozonation process for metronidazole degradation. Adv Powder Technol 31(2):875-885

Nawrocki J, Kasprzyk-Hordern, (2010) The efficiency and mechanisms of catalytic ozonation Appl. Catal B: Environ 99:27-42

Nie Y, Xing S, Hu C, Qu J (2012) Efficient removal of toxic pollutants over $\mathrm{Fe}-\mathrm{Co} / \mathrm{ZrO} 2$ bimetallic catalyst with ozone. Catal Lett 142:1026-1032
Rice RG (1997) Applications of ozone for industrial wastewater treatment. A Rev Ozone Sci Eng 18:477-515

Salman MS, Alwared AI, Mohammed NA (2020) Photocatalytic Degradation of Reactive Yellow Dye in Wastewater using H2O2/ TiO2/UV Technique. Iraqi Journal of Chemical and Petroleum Engineering 21(1):15-21

Sotelo JL, Beltrán FJ, Benitez FJ et al (1989) Henry's law constant for the ozone-water system. Water Res 23:1239-1246

Staehelin J, Hoigne J (1985) Decomposition of Ozone in Water in the Presence of Organic Solutes Acting as Promoters and Inhibitors of Radical Chain Reactions. Environ Sci Technol 19(12):1206-1213

Sun Q, Lu J, Wu J, Zhu G (2019) Catalytic ozonation of sulfonamide, fluoroquinolone, and tetracycline antibiotics using nano-magnesiumhydroxide from natural bischofite. Water Air Soil Pollute 230:55

Tran NH, Reinhard M, Gin KYH (2018) Occurrence and fate of emerging contaminants in municipal wastewater treatment plants from different geographical regions-a review. Water Res 133:182-207

Trovó AG, Nogueira RF, Agüera A, Fernandezalba AR, Sirtori C, Malato S (2009) Degradation of sulfamethoxazole in water by solar photo-Fenton. Chem Toxicol Evalu Water Res 43:3922-3931

Wang J, Zhuan R (2019) Degradation of antibiotics by advanced oxidation processes: An Overview. Sci Total Environ 146:012048

Yan H, Lu P, Pan Z, Wang X, Zhang Q, Li L (2013) Ce/SBA-15 as a heterogeneous ozonation catalyst for efficient mineralization of dimethyl phthalate. J. Mole. Catal. A 377:57-64

Publisher's Note Springer Nature remains neutral with regard to jurisdictional claims in published maps and institutional affiliations. 